DEFINING THE NEED FOR A NEW PARADIGM FOR THE REDEVELOPMENT OF SUBURBAN FORM

\author{
by
}

Christopher Roland Correia, B.A., Simon Fraser University, 2007

\author{
A Major Research Paper \\ presented to Ryerson University \\ in partial fulfillment of the requirements for the degree of \\ Master of Planning \\ in \\ Urban Development
}

Toronto, Ontario, Canada, 2011

(C) Christopher Roland Correia, 2011 

I hereby declare that I am the sole author of this major research paper.

I authorize Ryerson University to lend this paper to other institutions or individuals for the purpose of scholarly research.

I further authorize Ryerson University to reproduce this paper, in whole or in part, by photocopying or by other means, at the request of other institutions or individuals for the purpose of scholarly research.

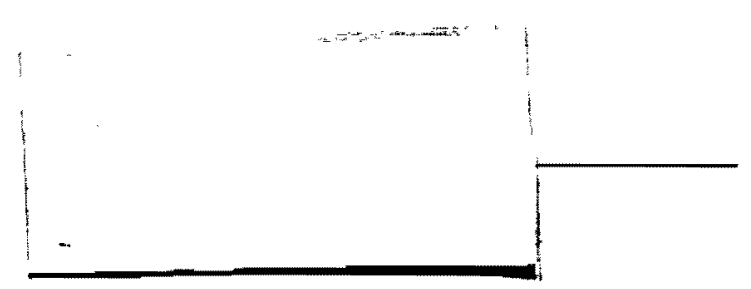


$\Rightarrow \quad-\quad$

$+\infty+\cdots+\cdots$

$-$

, 


\title{
DEFINING THE NEED FOR A NEW PARADIGM FOR THE REDEVELOPMENT OF SUBURBAN FORM
}

\author{
(C) Christopher Roland Correia, 2011 \\ Master of Planning \\ in \\ Urban Development \\ Ryerson University
}

\begin{abstract}
Planning started as a profession to maintain a better quality of life by managing the negative effects of human settlement. Anticipated improvements in health derived from the adoption of single-family dwellings have failed to materialize across North America. Attainment of this better quality of life can only come from life in urban environments. The only way to ensure society's survival is to refine our means of living, shifting away from one that consumes resources beyond the Earth's carrying capacity. Our society must begin to question the path of development selected by articulating the need for a drastically different development paradigm. Without this discussion, our society will inevitably use more resources to sustain our lifestyle than our planet can allow.
\end{abstract}

Key words: urban planning; paradigm; suburbs; conservation; health; expropriation 



\section{Acknowledgements}

I must begin by thanking my supervisor, Ron Keeble, for offering his immense passion towards the evolution of my topic as well as his perseverance in ensuring that I finish. I would like to thank my second reader, Leo Longo, for offering comments during this process. Finally, I must thank my colleague, Mark Antoine, for his continued support throughout this endeavour - if only we stuck to the plan. 



\section{Dedication}

To my family. 



\section{Table of Contents}

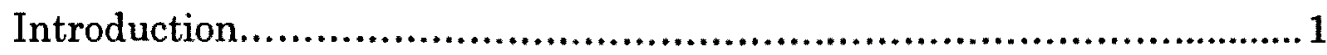

Problem Investigation............................................................. 5

Collective versus Individual Resource Use............................. 6

Infrastructure..........................................................11

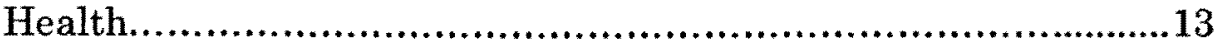

Existing Development Paradigms........................................16

Garden City....................................................... 16

Levittown............................................................. 19

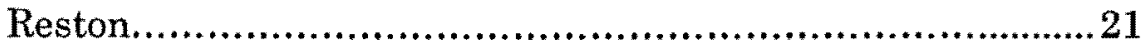

Master Planned Estates..............................................22

Literature Summary ............................................... 24

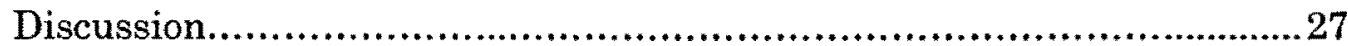

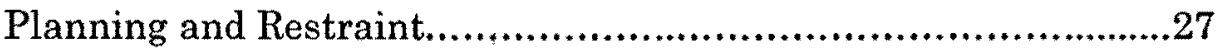

Why Development is not Going Ahead...................................... 28

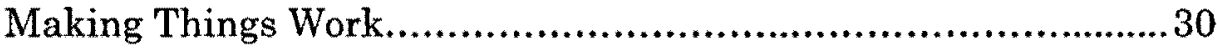

Ontario's Provincial Role....................................................... 33

Development Paradigm Attributes........................................... 37

One Version of the New Paradigm........................................... 39

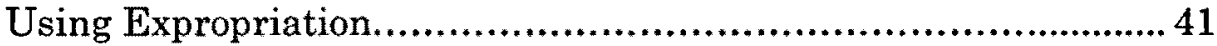

Why Expropriation........................................................43

Engaging the Private Sector.......................................... 47

Recommendations................................................................. 51

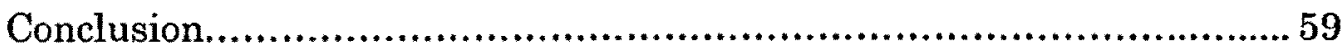

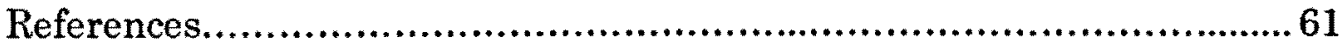




\section{List of Figures}

1. Langstaff Gateway Land Use Proposal........................................40 


\section{Introduction}

Planning started as a profession to maintain a better quality of life by managing the negative effects of human settlement. This desire to advance human well-being encountered a modification during the second half of the $20^{\text {th }}$ century, when the use of single-family dwellings were deemed to provide the most appropriate form of housing for a healthy environment. Since that time, North American society in particular has continued on a path to entrench single-family dwellings as the undeniable best practice in delivering a healthy population.

Through the course of settlement growth, the focus of planning shifted away from maintaining quality of life on a collective basis to one that is focused on serving the interests of an individual through the proliferation of single-family dwellings. Society now faces a significant stumbling block as the negative externalities of single-family dwellings are impacting the collective well being of society.

Policy decisions directly informed the physical problems that are now faced, which can only be corrected through further policy decisions. Our decisions in the future must be shaped by policy that is built on a foundation of preserving the ability for our planet to sustain ourselves by not living outside of our carrying capacity ${ }^{1}$. Believing that contemporary generations can consume more resources than what is available in the natural environment is naïve - there is a limit to our resource consumption. Entrenching the absolute need for people to use fewer resources in meeting their daily desires, in part through the type and location of dwelling will help facilitate a move towards conserving our resources for future

\footnotetext{
${ }^{1}$ Carrying capacity is defined as the maximum population size of a species that the environment can sustain indefinitely given the availability of food, habitat, and water
} 
generations. Without change to our wasteful resource use, our society as is currently know will not be able to survive. While resources may seem plentiful at the moment, society as a whole has to view the environment within a long-term perspective to adequately readjust our actions.

Is it possible to establish a foundation for a new redevelopment paradigm that transforms inner-ring suburban land - the first group of single-family dwellings built around the urban core - into more economically, environmentally, and socially sustainable forms? If so, what are the key components of this new paradigm and why would it have merit?

This paper will help define the need for a new paradigm for the redevelopment of inner-ring suburban form. Inner-ring suburban form is the first ring of single-family dwellings built outside of multi-family dwellings originally found in the first urban core. This area is selected because of the proximity to, and opportunity to connect to existing density. Underutilized land found within this development type does not take advantage of the potential to utilize the infrastructure capacity of urban areas.

Reexamining the premise behind planning's purpose will help focus the positive qualities about a new paradigm. Highlighting the importance of quality of life and standard of living, and how those two terms relate to restraint and resource conservation are imperative for this discussion. A discourse analysis ${ }^{2}$ will be the primary method to understand the circumstances in which to redefine the need for a new development paradigm.

${ }^{2}$ A discourse analysis is a method of reviewing a discussion utilizing multiple perspectives 
Foremost amongst the different perspectives is the field of public health, the original home of planning. Without this frame of mind as a guide, other perspectives that treat health as a secondary concern will inevitably guide planning. Of course, health is ambiguous at times, and may not accurately define the scale at which planning decisions should be reviewed. Nevertheless, there is a moral requirement to judge how effective land-use development is at delivering a healthy environment for society. Solutions have to not only meet the needs of people and the environment, but also have to fit within the realm of public acceptance.

Theory has provided an insightful opportunity to view the distinction between what was proposed and what occurred, allowing this study to examine the opportunities and constraints of different models. The system of evaluating the merits of paradigms within theory is rooted in ambiguous standards due to the inherent trouble of qualitatively measuring success. Next, a look at the positive and negative attributes of existing development paradigms present within North American regions will be reviewed. A collection of attributes that need to be included within a new paradigm for the redevelopment of inner-ring suburban land will be presented.

Institutional and legal frameworks are to be included in the analysis to develop an understanding of how they facilitate the status quo and how they inhibit adaptive change. To ground this section of the research, the Ontario context will be used to review the government framework, including the planning process and legal acts to surmise the existing constraints and opportunities. To accomplish the incorporation of this paradigm in the land development process, the need for municipalities to more readily utilize the ability to expropriate land in these areas will be defined as the necessary step in changing suburban form. 


\section{Problem Investigation}

The focus is on establishing the need for a new redevelopment paradigm. It can be said that two reasons are pushing us to reexamine our forms of development. One, a need to conserve our resources to last longer - this begins with the way that land is developed. Secondly, a need to focus on health has to come back to the forefront. This view has been lost when planners started to ignore the negative externalities created through the creation of single-family dwellings. There are problems derived from single-family dwellings that will not go away, so there is a need to look at more efficient uses of land. If the status quo does not change, then our resources will continue to be foolishly consumed for decades to come.

A healthy urban population was one of the founding reasons for the creation of the field of planning and it is only right that this field be used to guide research into the current problem that suburban areas face. The foundation to any further research is predicated upon understanding the true definition of health. The World Health Organization (1948) defines "[h]ealth [as] a state of complete physical, mental and social well-being and not merely the absence of disease or infirmity". The product of a half-century of planning, suburbs have created a wide variety of unintended physical and psychological health-related problems. As health is the product of one's environment, understanding how our environment is used must first be reviewed. 
The problem with measuring what good is to a person is that it is subjective, it is difficult to compare because it is incommensurable. When people have different standards, society ends up with competing, diverse demands that create conflicts. These standards are naturally distributed among classes and then defined as group conflicts. It seems that as the conflict becomes more important, the division between classes increase as the number of classes diminish. At the moment, this distinction in standards is distributed according to limited government regulation in land use, ultimately directed by the market.

The Wealth of Nations (1776, as cited in Hardin, 1968) highlighted the idea of the invisible hand and the influence that individuals had in making their choices in their own best interests that would ultimately promote the public interest. The idea that the invisible hand leads to a greater public interest was not promoted as true and valid. However, the widespread promotion of the idea propagated its validity. As such, the right of individuals to do as they please needs to be reviewed to determine which actions need to be controlled (Hardin, 1968). Edney (1980, as cited in Sheldon \& McGregor, 2000) positions the conflicts that arise between individuals and group interests, along side a divide between resource use in the near future and long-term use.

The Tragedy of the Commons, as Hardin (1968) states, is the point at which people aimlessly exploit resources to a point where it leads to human unhappiness. Pursuing one's best interest in the context of limited restrictions will bring ruin or human unhappiness to all. Sheldon \& McGregor (2000) found through their studies that extrinsic values promoted the notion of "the tragedy of the commons". They found, on average, that extrinsic participants accumulated more resources, but 
ended up consuming all the resources earlier than intrinsic participants. Overall, while intrinsic individuals did not have a clear advantage over extrinsic individuals, they found that with more intrinsically-oriented people in a group, the better the group prospered. Based on this finding, intrinsic values and the communication of this idea throughout generations should be supported (ibid).

Through education, people can be made aware of this problem and correct it, however, new generations develop and need to be made aware (Hardin, 1968). Although, the same idea applies to the invisible hand - the difference is in the shift of focus. Educating people about the need for reforms to the idea of the invisible hand is possible through coercion (ibid). Coercion should not be based on irresponsible behaviour, but from a mutually agreed upon decision from those affected the most.

Messick, Allison, \& Samuelson (1988, as cited in Sheldon \& McGregor, 2000) state that the problems of resource extraction can be managed by communication among group members, or, as Brewer \& Kramer claim (1986, as cited in Sheldon \& McGregor, 2000), when group members have a collective identity or solidarity, or if the communication given attributes the long-term benefits of cooperation (Allison \& Messick, 1985, as cited in Sheldon \& McGregor, 2000). Public dialogue, therefore, is part of the answer in bridging the gap between privately-made decisions based on individual concern and those decisions that are based on collective concern. Increasing the awareness behind the reasoning of publicly-made decisions is critical to public acceptance.

Any proposal to restrict freedoms will be faced by opposition based on two assumptions: that the status quo is best; or that the proposed reform is imperfect and should be ignored until a better solution is found (Hardin, 1968). 
People within society can be characterized as one of three types based on their Social Value Orientation: co-operators (those concerned with happiness of self and others), individuals (those concerned with self maximization), and competitors (those concerned with maximization of the difference between their own maximization and others) (Kuhlman \& Marshallo, 1975; Messick \& McClintock, " 1968; Van Lange, Otten, De Bruin, \& Joireman, 1997, as cited in Sheldon \& McGregor, 2000).

The influence of intrinsic and extrinsic individuals within unspecified strategies in solving social problems has been explored, but offers no solidified view as there are advantages offered to both sets of individuals (Patchen, 1987; Rapaport \& Orwant, 1962, as cited in Sheldon \& McGregor, 2000). While people have competing perspectives on how to interact with others, the reason that certain perspectives exist can be further defined. Kasser (2002, as cited in Brown \& Kasser, 2004) found through research that intrinsically oriented people (those with values focused on personal development, relationships, and community participation) reported greater well-being than those people who are extrinsically oriented people (those with values focused on money, image, and status). Burch (2000, as cited in Brown \& Kasser, 2004) and Rosenberg (2004, as cited in Brown \& Kasser, 2004) have suggested that individuals with mindfulness (a level of consciousness) tendencies may be able to reflect on the impact of their consumerism on the environment.

Altruism is characterized as self-sacrificing behaviour, different than restraint which is deemed to be self-interested behaviour. Overlap between the terms may be expressed, however, restraint is viewed with objectives for long-term economic security or collective benefit; two ideas that follow self-interest thinking 
(Princen, 1997). Restraint is closely related to conservation as a means of reducing consumption and resource use. In society, conservation can be activated by regulation as well as societal norms. The key distinction between the two terms is that restraint is rooted in self-management focused on developing a secure and dependable [support] system. The motivating feature behind restraint is that it is imperative for people to adhere to this perspective for their survival. Here awareness and incentives help but do not contribute to final adoption (ibid). The premise behind reducing consumption is the expectation that non-material benefits will increase, including group approval, and a reduction in economic uncertainty.

Two sources of restraint are highlighted, including economic calculation and social norms. Economic calculation incorporates substitution in the form of reducing an immediate economic need for a non-economic need (ibid). Social norms offer the greatest potential to guide consumption activities based on psychological and institutional levels (De Young, 1993, Katsev \& Johsnon, 1987; Ostrom, 1990; Young, 1989, as cited in Princen, 1997). As society continues to cater to a technologicallydriven economic system the ability to instil these norms is the most difficult task (Princen, 1997).

A survey conducted on adults in differing lifestyles found that people with a more ecologically sustainable means of living reported greater personal well-being. Being conscious of one's actions complemented by their set of intrinsic values would lead to benefits for the individual and ecological well-being (Brown \& Kasser, 2004). People with intrinsic values are unlikely to desire objects which place importance on extrinsic values (money, image; status), such as large houses (ibid). Maslow (1954, 1956, as cited in Kasser \& Ryan, 1996) and Rogers (1961, 1963, as cited in Kasser \& Ryan, 1996) highlight that people are in a position of distress when they act in ways 
necessary to gain the approval of others, instead of focusing on acts that will address their own needs. Having a high level of intrinsic motivations was associated with a dramatic rise in well-being and vitality and dramatically less depression and physical problems (Kasser \& Ryan, 1996). The focus on community and relationships furthers individuals to decrease their ecological impact in order to * benefit future generations (Kasser \& Ryan, 1996, as cited in Brown \& Kasser, 2004). The importance of mindfulness in the economy must be understood as powerful tool to sway the market towards ecologically-sensitive goods and services (Rosenberg, 2004, as cited in Brown \& Kasser, 2004).

Currently, resources are managed based on tradeoffs or economic margins. When the use of restraint influences market behaviour, non-material benefits are pursued over material benefits. Non-material benefits include: economic security, self-reliance, social acceptance, and personal health (Princen, 1997).

Ideally, society needs to reach a level of resource consumption that meets the regenerative level in order to develop the ultimate form of consumption. Continual increases in resource consumption are ecologically and thermodynamically impossible (Ehrlich, Ehrlich, \& Holdren, 1993; Georgescu-Roegen, 1993, as cited in Princen, 1997).

The precondition for engaging in restraint is to have effective feedback from resource consuming behaviour. To have effective resource management among property regimes (public and private) is to ensure that boundaries are placed on the resource and that the political environment ensures property rights (private or public ownership) to facilitate long-term benefits (Princen, 1997). A fine line must be drawn with the presence of public land ownership in a capitalist society. At some point there is a collective benefit in public ownership or control of property. 
Economic security, not material value holds the key to showcasing restraint and motivating one to work in their self-interest in a non-material way (ibid). This perspective works to further both consumerism and environmentalism by focusing on cooperation between the two. People are naturally focused on their own selfinterest; there is no need to coerce them to think of themselves as global citizens or environmentalists (ibid).

\section{Infrastructure}

Self-interested people are naturally accepting of decreased costs and improved benefits to their health. The provision of infrastructure is fundamental to the operation of the human environment through the movement of people and goods. Without adequate operation of these services, economies, and in turn people, will not be as efficient (and profitable). Reduction in efficiency hurts all of society, not just those people exposed to it.

Directed, managed growth is more appropriate because you can centrally focus uses, resources are not quickly consumed (compared to sprawl) and the amount of residential and commercial development is not altered (Burchell \& Murkerji, 2003). Dewees (2002) suggest there are three conditions to maximize public welfare including: achieving allocative efficiency, that is, when the efficient output is produced and charged at the price of producing an additional unit, or marginal cost (Varian, 1990, as cited in Dewees, 2002); rationing efficiency should be instituted in times of production limitations, the price of a product should go up and be paid for by those who value it the most; and cost efficiency, the need to produce goods at the lowest social cost (Dewees, 2002).

Generally, the fewer resources used to serve residents results in a cheaper 
overall cost. In fact, it appears that this suggestion is true. Burcher et al. (1998, as cited in Mirza \& Haider, 2003) found that it is $30 \%$ cheaper to build local roads within compact development than sprawl-oriented development. Supported by Duany, Plater-Zyberk, \& Speck (2000) who state that traditional urbanism is often cheaper, even with rear lanes, as there is no need to build driveways. Whereas Speir \& Stephenson (2002) conducted a cost simulation of providing water and sewer services, finding costs doubled when lots increased from 0.25 to 1 acre, along with a $30 \%$ increase in costs when lots increased from 0.25 to 0.5 of an acre. The simple fact is that as the distance from developments to infrastructure service centres grows, costs must increase.

Essiambre-Phillips-Desjardins Associates (1995, as cited in Slack, 2002) compared emplacement, replacement, and operating costs of a urban sprawl development and a compact development and found a $8.8 \%$ savings over 75 years life-cycle. Burcher (1992, as cited in Mirza \& Haider, 2003) and Esseks et al. (1999, as cited in Mirza \& Haider, 2003) claim that maintenance costs are also lower for compact development than sprawl development. Still, reinvesting in capital infrastructure can enhance a city's overall image which can help in making it more economically competitive and provide a better quality of life for its residents (Brittain, 2002).

Many urban areas have options available to redevelop existing areas rather than developing greenfields as it would appear to be a more efficient use of space. Blais \& Berridge Lewinberg Greenberg Dark Gabor Ltd (1995) found that sprawl development would require $\$ 10$ to $\$ 16$ billion dollars more in infrastructure costs than redeveloping existing urban areas.

Providing large amounts of infrastructure to service suburban environments 
is often not fully recovered through development charges and user fees. When density and built form are not factored into development charges, then the market becomes distorted and an inefficient use of resources is present (ibid). Conversely, Lewis (1999) asserts there is no need to consider the cost of infrastructure needed to support sprawl development as the purchasers ultimately pay for the costs, which is simply a market decision. Bringing transparency into the operation of development is absolutely necessary for people to understand the total cost of their living. If property owners pay the true cost for the services they consume, they will relocate to the most efficient space possible to reduce costs.

\section{Health}

With a rise in documented problems faced by suburban residents, more attention has been garnered towards understanding the problem at hand, increasingly overshadowing existing marginalized inner-city residents. This concept known as the 'urban penalty', first described by the $19^{\text {th }}$ century urban movement for social justice (Ham, 1998, as cited by Freudenberg, Galen, \& Vlahov, 2005), is now being counteracted by the prominence of suburban problems at the expense of urban health problems (Freudenberg et al., 2005).

There are varying theories on the degree to which living environments determine the health of individuals. One model suggests three 'fundamental determinates of living conditions', including economic, political, and social factors across all levels of government (ibid). The critical importance of this model is that it views all areas of urban areas as important to the health of society since the centre and the periphery contribute to the way of life and are defined by interventions from public health operations. A related model is offered by Fan \& Song (2009) who build 
on a conceptual model developed by Kliztman et al. (2006, as cited in Fan \& Song, 2009) which conceives of the built environment, mediating factors, downstream pathways, and health status as key influencers. Regardless of which model is used, both suggest multiple influences throughout the built environment play a role in shaping the behavior of individuals.

Compact, urban environments with high levels of accessibility [through a grid street network, mix of land-uses, and identifiable centers promote walking as the dominant form of transportation leading to healthier behavior (Kelly-Schwartz, Stockard, Doyle, \& Schlossberg, 2004). Whereas Plantinga \& Bernell (2007) cite poor connectivity amongst the street network found within suburban form, which creates barriers for walking and cycling, making it less safe and impractical; as well as reducing the viability of transit, creating incentives for driving; and the reduction in available parks, restricting physical activity.

Longitudinal studies have shown that once smart growth measures were enacted, mortality rates declined (Fan \& Song, 2009). Demonstrated reductions in weight loss were also observed over time as individuals moved from less to more dense areas, with greater changes observed with more drastic changes in density . (US National Longitudinal Survey of Youth, 1979, as cited in Plantinga \& Bernell, 2007). Supporting research found a positive correlation between people living within urban sprawl and inadequate amounts of physical activity (Garden \& Jalaludin, 2002; Ewing, Schmid, Killingsworth, Zlot, \& Raudenbush 2003).

On the other hand, Lee, Ewing, \& Sesso (2009) conducted a cross`sectional and longitudinal study of 3,448 men over five years and found that those who moved to less sprawling counties did not engage in more physical activity, likely due to selection bias in determining a neighborhood that met their physical activity needs. 
Kelly-Schwartz et al. (2004) find that a dense built environment may not be conducive towards increased physical activity as it is less inviting and more stressful, as opposed to sprawl, which may present less hassle and be more pleasant for some.

There is overwhelming support from researchers on the rise of BMI through a reduction in physical activity due to walking less and living in a car dependent environment (Kelly-Schwartz et al., 2004; Ross, Crouse, Tremblay, Khan, Tremblay, \& Berthelot, 2007). Any assumption that this change is due to a modification in genetics is unfounded claims Santana, Santos, \& Nogueira (2009). While Benfante (1992) finds a positive relationship between immigrant status and a lower BMI for men and women, this relationship diminishes over time as they absorb the living habits of their environment. This change occurs regardless of ethnicity (Tremblay, Pérez, Ardem, Bryan, \& Katzmarzyk, 2005).

Invisible psychological and social problems are manifesting within suburban areas due in part to the type and amount of social interaction. Limited opportunities for daily interactions create reduced sense of place in communities, along with fostering incivility contributing to a degradation of respect for others (Morris, 2005). With a breakdown in civility and a remote sense of community, property crime increases and creates impressions that the community is not safe persuading lower levels of physical activity in the higher and contributing to higher BMI (Santana et al., 2009). This breakdown in civility is contributed to in part by children growing up in secluded and structured environments, inhibiting the development of key interpersonal skills needed to develop and maintain relationships (Morris, 1994, p. 96; Langdon, 1994).

Strong social interaction within a community has proven to maintain proper 
health with less psychological problems than those in isolation (Holahan, 1982, p.322). Morris (2005) claims being recognized amongst social interactions, as being therapeutic and this theory would supplement work by Santana et al. (2009) documenting strong social capital, including local recreation sports associations as increasing the amount of physical activity. Social support is key to preventing many types of depression says Siberski (as cited in Thompson, 2003).

\section{Existing Development Paradigms}

Both arguments offer important reasons to move towards smaller, more efficient development paradigm. Concerning existing development paradigms, this paper will look at the positive and negative characteristics of a few influential concepts including: Ebenezer Howard's Garden City, Levittown, Reston, and Master Planned Estates.

\section{Garden City}

The primary focus of the Garden City model was to address social issues, the physical form resulting from this focus was only a secondary concern (March, 2004). The social ideals that formed the direction was based upon collective ownership of land (Hall \& Ward, 1998; Purdom, 1913, as cited in March, 2004), which allowed rents to be controlled to a level necessary to provide social services. As towns would be built in rural areas, the lift in value from the original land use and the new town uses would be collected by the municipality and directed to offset social services rather than the private sector (March, 2004).

Planning's importance can be defined by the benefits of collective action and long-term thinking, including equitable resource use, integrated infrastructure, and 
environmental sustainability. Ensuring this process is conducting in a democratic manner would involve a careful balance between managing the rights of individuals and the collective interest (ibid).

March (ibid) classifies democracy as antinomy, a situation in which inclusive government provides the right to have a healthy environment while still allowing unrestricting rights to the use of a person's land. Howard's vision was based on developing a community that utilized as little bureaucracy as possible to deliver the benefits of planning, while providing people with individual freedom (Fishman, 1977, as cited in March, 2004).

The importance of the environment and how it influences behaviour is mentioned by Owen in $A$ New View of Society (1991, as cited in March, 2004) who stated that influences, including competition, religion, or poor living conditions, contributed to poor social conditions such as being selfish and irrational.

A central aspect of the Garden City is the provision of both private and public services. However, the allocation of services between both components was not determined by Howard (1898, as cited in March, 2004). The two components were expected to be supplemented by a third source of funding, philanthropy, as Howard's town \& country magnet was annotated by the words "freedom \& co-operation". Regardless of the ideological view, experience in Letchworth and Welwyn showed that investors did not seek any less of a return on their investment (March, 2004). This desire for a return on investment contributed to a reduction in democratic control of key municipal decisions as a board of directors was used rather than local representatives, whose decisions were obviously based on economic conditions (ibid).

Providing rights within a democratic system is faced with the inherent problem in defining the principles that are used to establish the foundation 
(Sumner, 1984, as cited in March, 2004). Utilitarianism, founded by Bentham, states that natural rights are as "simple nonsense: natural and imprescriptible rights, rhetorical nonsense - nonsense upon stilts" (Bentham, 1961, as cited in March, 2004). He believed that utility should be defined by the overall benefit to society and that this be the goal of government. Whereas, classical utilitarians. believe that utility can only inform governance if individual rights are not considered beyond a feeling of pleasure or pain (ibid). The rights-based approached recognizes the individual interest (Mackie, as cited in March, 2004). Going back to utilitarianism, it is consequentialist as it does not view rights beyond the individual's feeling of pain or pleasure, just the total sum of pain or pleasure felt by all affected people (March, 2004). When looking at the influence of the market in the utilitarian-oriented society, the right to gain your rights or utility is based on the market and the ability for a person to gain those rights through money (ibid).

Within the confines of rights exists two further concepts: liberty and equality. Both cannot co-exist fully as the right of liberty ultimately infringes on equality and providing equal resources restricts freedom (ibid). Further, liberty can be understood as liberty to and liberty from. Liberty to is the ability to act without constraints (Janda, Berry, \& Goldman, 1987, as cited in March, 2004). Equality is further understood in three areas as: of outcome; of opportunity; and political equality. Equality of outcome is based on government making all individuals equal. Equality of opportunity is premised on the idea that everyone has the same opportunity, without concern for outcomes. Political equality is concerned with equal access to the political process (Janda, as cited in March, 2004). 
Advocates of the Garden City model, as Unwin stated, was to avoid the separation of economic classes which was prevalent in English towns (Hall, 1988, as cited in von Hoffman, 2009).

Levittown

Levittown was started in the spring of 1947 by Levitt \& Sons as a means to house returning veterans in affordable bungalows. The National Housing Act of 1934 was amended to make the production more affordable. Part of the reason why government was interested in these policies is that it helped returning veterans become employed again, facilitating economic expansion, without appearing to create make-work projects. It has followed traditional ideals of private property, personal initiative, and free enterprise. Coupled with efficient building models to make housing construction cheaper and faster, the large amounts of recently foreclosed farms created large amounts of land available to redevelop (Kelly, 1993).

A general lack of apparent opposition helped the project develop; even the local Town of Hempstead altered their building code to allow slab-based construction. There was opposition to the project from neighbouring communities and elites, however, the promise to house returning veterans proved too much and the only impediment was over details of building and zoning regulations (ibid).

Abraham Levitt (Island Trees Tribune, December 12, 1947, as cited in Kelly, 1993, p.36) wrote that Island Trees development had been planned to be a place of "incomparable beauty... a complete, integrated, harmonious community". The initial intent of the community failed to deliver a true planned community as William Levitt, in 1964, stated that the worst thing about the community was that it did not 
start with a comprehensive plan; rather, it worked on an incremental-based planning framework.

Based on the success of Levittown, in 1959, the U.S. Federal Housing Administration institutionalized many of planning and design elements found there for future suburban developments. These elements helped form the American character through a growing consensus about the role the house had in defining its formation. This ideology helped solidify the notion that home-ownership was the most appropriate form of housing (Kelly, 1993).

Levittown overall was not a planned community in the traditional sense, it did not seek to address all aspects of a person's life. Rather, it was an intentional community built to support homeownership at the same time as avoiding the creation of social and political problems (ibid).

Single-family dwellings in Levittown were designed to be very affordable for the working class (blue-collar and emerging white-collar workers) by designing houses for sale at no more than double their annual income. This feat was accomplished by having no more than four rooms in a house (ibid).

There is a strong promotion for property ownership at the time as a way to avoid socialist ideologies and focus on economic prosperity. The idea was that land ownership is an insurance policy for people to look after their own best interests, a capitalist mentality (ibid).

The homogenous nature is one of the key criticisms of the development based on social and aesthetic reasons. Levittown's design emulated the problems of apartment living alongside those of private property ownership. These homes provided no extra space for activities with the limited four rooms while offering the loneliness of a privatized lifestyle (ibid). 
Reston

Created by Robert Simon in 1962, Reston differentiated itself from traditional mid-century developments, master-planned or otherwise, based on the focus of high-density corridors with townhouses and apartments framed in a village setting, flanked by limited numbers of single-family dwellings. These villages would offer the necessary services to be deemed a complete community, including commercial and cultural facilities. Employment would be focused in office park developments located nearby to reduce total commuting times (Bloom, 2001).

The guide for Reston was to be a place based on human needs, facilitated by the proper mix of educational, intuitional, residential, and industrial uses. Once these ideals were finalized, the physical plan at which these ideals were to be placed was developed. A hybrid of traditional suburban development was mixed with the garden city paradigm as a way to create a new town (ibid).

Rather than concentrate density along concentric rings, the idea of Reston was to scatter density across the town to make it more far-reaching in nature. Through the use of innovative, high-quality architect-designed housing, the legitimacy of this suburban community was increased compared to traditional suburban communities. Based on the time of development, the design of Reston gathered design cues"specifically having modernist buildings built around natural features-from European towns being rebuilt after World War II. Unlike individual yards with alleys as found with traditional suburban planning, Reston was designed with landscaped common places behind houses which were instituted to facilitate community and neighbourhood cohesion (ibid)

Schools often serve as the central focus in suburban neighbourhoods, but not. in Reston. Instead, cultural, recreational, and commercial facilities were designed to 
be central to the community with schools being relegated to outside, convenient locations. This focus goes back to his inspiration that Reston should be a place based on human needs, one that can stimulate and captivate attention. Each central village was designed around different recreational activities, which ended up influencing the architectural design of the village (ibid).

While the design was contemporary, it did not appeal to a large enough demographic, making it hard to sell units. Compounded by the semi-remote location relative to the urban core, the community was unable to turn a profit. This contributed to changes in ownership and management that sought to increase the presence of single-family dwellings in the community as a way to increase profit (ibid).

\section{Master Planned Estates}

Master Planned Estates (MPEs) were designed to facilitate the affirmation of elevated ethnic and class positions (McKenzie, 1994; Gwyther, 2005; Glesson, 2006a, b, 2008; Goodman \& Douglas, 2008, as cited in Johnson, 2010). The opportunity to : develop MPEs only arose with the failure of traditional post-war suburbanization (Johnson, 2010).

Large-scale comprehensive planning of existing towns and neighbourhoods only transpired through the introduction of state intervention in Victorian England and Napoleonic France (Cherry, 1974, as cited in Johnson, 2010). The introduction of planning was premised on the need to address the problems of industrialization: environmental, social, and political-while delivering greater control to local authorities (Johnson, 2010). 
It is suggested that master planning is based on utopian and authoritative ideologies as well as rooted in large scale, comprehensive transformations facilitated by altered government structures and funding mechanisms (ibid).

Growth of the suburbs in the early $20^{\text {th }}$ century were characterized by writers as materialistic, conservative, and parochial (Rowse, 1978, as cited in Johnson, 2010). After World War II, the political left classified suburbs as places with poor aesthetics, unnatural social conformity, and mediocrity (Johnson, 2010).

In Australia during the $20^{\text {th }}$ century, the costs associated with suburban form and concurrent population shift away from the inner city lead to urban intensification and master planning (Logan, 1986; O'Conner et al., 1995; Troy, 1996, as cited in Johnson, 2010).

Master planning faired well in the 1980s based on it's neo-liberal focus allowing the private sector to help deliver services and infrastructure; the beginnings of public-private partnerships (Johnson, 2010).

The use of MPEs targeted a specific market looking for social and physical segregation that would serve their economic and cultural security. These developments have supported residents' desire for a largely middle-class environment that would affirm their power as a status group (Gwyther, 2008, as cited in Johnson, 2010). The physical delimitation of these neighbourhoods, with marked entrances of perimeter walls, helped produce a sense of identity and gave a sense of security (Johnson, 2010). 


\section{Literature Summary}

Two central arguments now exist for the need to define a new development paradigm for suburban form. Allocation of resources and health have been articulated as two necessary reasons as to why our view of development must be altered. Collective interest often contradicts individual interest at the scale in which development occurs. Due to the large number of externalities, the allocation of resources between individuals, along with the rate of resource use across generations, must inform development to a degree than is currently the case. Ultimately, global society has a responsibility to use our resources more efficiently. While efficiency may be viewed in the context of exploiting as many resources as possible to profit, society must change their perspective to understand that the best long term efficiency, or profit, can only be attained by restraining ourselves.

The need for an efficient allocation of resources must be viewed in the context of the provision of infrastructure. Through the movement of people and goods, infrastructure is fundamental to the operation of the human environment. Existing infrastructure used to support suburban form is inherently inefficient as it adheres to an inefficient use of space, ultimately costing society more money than necessary.

Human health was the reason that the planning profession formed.

Suburban form was deemed in the $20^{\text {th }}$ century to bring better health to individuals as they fled the ills of the city. With the proliferation of suburban form, people living in these areas now are plagued by multiple forms of health problems, including physical and social ones. Physical form of this environment is the main cause of these problems as car dependence has shifted the reliance away from active forms of transportation. Alongside the tendency for people to gain additional weight from their sedentary lifestyle, the monotonous and secluded nature of suburbs have 
facilitated the established of new social situations. These situations have contributed to psychological problems for people as they have lost the ability to interact with people on a level needed to function adequately within society. These psychological problems facilitate a cycle of health problems as they contribute to the establishment of physical health problems.

Finally, four development paradigms, Garden City, Levittown, Reston, and Master Planned Estates provide a view of the types of land forms that been created in North America during the last century. Generally, these paradigms are based on low-density designs with limited options for a mix of uses and were focused on certain socio-economic classes. 


\section{Discussion}

Planning and Restraint

There are significant constraints placed on the environment due to resource use associated with suburban development patterns. North American society has formulated a conception of what has to be obtained by each individual, one that is rooted in consumption. Centred on the consumption of land in the form of singlefamily housing, people attempt to define their lives by the scale and opulence on their home. Complemented by the desire to consume personal possessions to be housed within these dwellings, people just keep buying. This behaviour would be condoned in almost any other field, but in the realm of planning, this unrestricted growth in resources only compounds the future problems that will be felt by society. Both in the trouble that society will face to adjust from this land-use pattern, but also in the time that is has to operate in a sustainable manner.

Carrying capacity should be the foundation for any development plan. If a community is not able to operate within the natural reproduction of utilized resources, then the characteristics of the development need to be altered to maintain a proper level of consumption. Society is simply using the existing resources of Earth at a pace faster than can be recouped through natural regeneration. Governments, as least the Canadian federal government, have known about this since the early $20^{\text {th }}$ Century. The Canadian Commission of Conservation outlined the need to live on the "interest of natural capital"; yet, in close to the last 100 years, society has not altered their desires to adhere to this ideology. Even with the influence of the Brundtland report, society failed to alter their behaviour.

It seems the only way to create a paradigm shift is to engage in a discussion about legal restrictions that would force a reduction in their environmental impact. 
A link between the use of sprawl and the negative impact it creates on the environment has to be established to start the consideration that these uses are improper, if not illegal. There should be a legal argument established in favour of eliminating the creation of further suburban form on the basis that it is unhealthy to the planet and society. Sprawl may be considered unhealthy to the planet overall, if so, it has to be seriously considered as a soon to be extinct form of land use.

Single-family dwellings are the biggest consumer of resources amongst our land-use patterns, yet, this is the one consumer of resources that residents encounter on a daily basis. It provides a frame of reference for our civilization that is paramount to defining our way of life. Due to this, this feature of our lives is the hardest to sway. Planning must be concerned about this because planners and politicians have to analyze land-use on a macro scale. Ignoring the externalities derived from our choices is not an option.

Why Development is not Going Ahead

Exploring the issue of forming a new development paradigm is brought about due to the lack of transformation of existing inner-ring suburban areas. If redevelopment was occurring, then there would be a limited need to invest attention into this issue. Understanding the obstacles to change is critical to inform discussion leading to policy changes. Generally, the political climate and economic conditions have the greatest influence on these areas and their propensity to undergo change,

Politicians, at the municipal and provincial level, have the ultimate decision in land-use decisions, meaning any potential to change the built environment rests with them. Interaction between both levels is intertwined leading to poor decisions 
informed through dual-perspectives, which are often contradictory. At the municipal level there are further aggravations when determining the direction of a region as a whole. Municipalities compete against each other, aimlessly focusing on their own self-interest, rather than that of the region.

While legislation cannot reduce or remove the ability for politicians to make decisions, planners can help inform their decisions. More information can help provide the opportunity to make better decisions, notwithstanding the tendency for them to ignore important information. Planners need to understand what informs their decisions right now. Underlying motivations have to be explored to expand areas of provocation. Perhaps, adoption of useful legislation would make their decisions easier if they were able to deflect criticism against a higher authority. This legislation, of course, is developed based on scholarly research. Removing any criticism from municipal leaders is crucial to enacting controversial policies.

Property owners seek to protect their investment through any means possible. The simplest ideology present amongst this segment of society is to avoid any infiltration of uses outside of their monotonous, single-family dwelling uses. The ever-present, engrained idea that a singular, low-density use preserves their economic well-being is misleading and plain wrong. Consumer choice has contributed to further creation of this built form. Along with a level of ignorance about the presence of other housing options (due in part to a lack of supply, which was derived from the initial market preference). Society in general has failed to educate people properly about such a complex system that is directed by politicians elected on popular vote.

With the vast majority of single-family zoned property owners focused on their own interest, this protection of the nest-egg mentality creates decisive me- 
against-them behaviour. Apprehension concerning changes to neighbourhoods resonates beyond economic issues. Social change to a neighbourhood, in the form of lower socio-economic groups moving in is a motivating factor for residents to demand protection. On the surface this issue may be premised on keeping neighbourhoods intact and stable, it ultimately reflects a desire to keep social classes separate to maintain property values.

Collectively, this behaviour cannot exist on a continuing basis until major problems develop. Society is at that stage now. The public entrust in their elected officials to provide this vision, through the recommendations of staff; yet, both areas of opinion fail to cooperatively lead.

Making Things Work

It is not sufficient enough to document positive development attributes to aim for and negative development attributes to avoid and expect they will be incorporated. Regions have long known of better ways to develop compared to the status-quo, yet, they remain largely untapped. Development requires fundamental inputs that cannot be significantly disturbed, including private capital, a solidified political climate, and a growing market.

Risk is a factor in any development. Private capital will always seek out the best return on investment possible and higher risk usually is rewarded with a bigger return on investment. However, risk also creates greater hesitation over engaging in projects. For land development to offer greater risk through changes to the type and method of development would provoke private capital to reconsider projects, which may lead to reduced amounts of property development. 
The political climate, on a municipal, provincial, and national level, all influence the tendency for development to commence and prosper. Reduced bureaucratic hurdles typically leads to faster approval times making the process less risky and more efficient, resulting in cheaper costs and prices for consumers. Typically a win-win situation results from such a limited amount of government intervention. These initial trade-offs often create short-term gain for the parties participating, inevitably delivering long-term problems for all portions of society. The key to avoiding long-term problems is to carefully restrict which portions of bureaucracy are reduced.

A stable, growing market economy is the last fundamental input that must be retained to encourage development. Significant deviations in the price of property alter consumer confidence undermining the ability for private capital to participate in the market. Consumer preferences support the type of development constructed and if they contradict the market will fail to grow. Of course, if the private sector builds a type they are in favour of, this will likely correlate to consumer preferences. There are two directions available under which appropriate methods can be found: market and non-market intervention. Depending on a person's political ideology, one or both avenues offer greater opportunity for change. For any change to the status quo to work, it has to reflect the aforementioned fundamental inputs and be cognizant of their importance. Market intervention would revolve around any method that seeks to increase the reliance on the market, or the collection of individual actions, to engage in progressive change. It is focused on incorporating greater government regulation in the planning of progressive change. Non-market intervention moves beyond facilitating the private sector by taking over a key role of the private sector in order to engage in change. 
Market intervention has to focus on reducing risk and ensuring developers have the easiest course possible in the process of development. One of the greatest challenges in land use is density and built form. If the maximum characteristics are known in advance it would make it much easier to determine the total number of units, retail or office space, or any other type of use. Pre-zoning land accomplishes this objective by zoning land with the same type and density of lands uses as envisioned under an official plan. With this information in mind, the value of the land used can be estimated and help reduce certainty for developers. Pre-zoning land would provide significant assistance to developers and would cut down on a large portion of the development approval process discussing variations to allowances.

Non-market intervention takes the position that the market is incapable of providing dramatic change necessary therefore more regulation is needed to push developers into the right direction. While increased government involvement is often viewed negatively as an inefficient operation, sometimes it is the only option available to correct the market deficiencies. An option to change land use patterns from random clusters of high-density land uses surrounded by low-density into a continuous densely-built environment may only be possible through government intervention. Ideally, government would be able to coerce development of highdensity buildings by getting the primary requirement, land, through the method of expropriation.

The private sector often fails to acquire enough single-family dwellings in inner-ring suburban lands for redevelopment through the market. Property owners typically require too much money for their properties when viewed from a developer's perspective when factoring in their profit margin. These prices are often 
elevated because of property inflation brought upon by inflated expectations during property bubbles. When inflated property prices do not contribute to high prices, other constraints remain as inhibiting factors.

As private property is transferred through private, voluntary transactions, important areas serviced by major infrastructure are restricted from redeveloping on the will of these private individuals. Political support for restrictions in development from these same property owners also restricts redevelopment. To curb both restrictions, expropriation would provide an avenue to offer additional land to the market. With the addition of more land open to redevelopment, the price for land will drop making it easier for market mechanisms to facilitate change.

\section{Ontario's Provincial Role}

- The Province must provide greater direction for growth in Ontario by defining the path for, and the location of redevelopment of suburban form, by exercising its existing legislative authority to direct the capacity of infrastructure provision along with growth of the region.

At the moment the Province of Ontario has two policies, the Provincial Policy Statement and the Growth Plan for the Greater Golden Horseshoe, which coordinate and direct growth on a provincial scale. The former is authorized under the Planning Act, whereas the latter is authorized under the Places to Grow Act. These two documents direct the growth of municipalities and require that each municipal official plan conform to both provincial policies. Due to the inherent influence present within these documents, growth should be further regulated to compensate for the inability of municipal councilors to engage in proper planned growth. 
The Provincial Policy Statement sets out that a settlement area shall be the focus of growth with densities that are an efficient use of land while utilizing opportunities for intensification and redevelopment. These policies do not well define where growth should occur outside of providing general policy guidance.

The location of provincial growth is set out in the Growth Plan for the Greater Golden Horseshoe. Growth centres are identified across the plan, including five within the City of Toronto (Growth Plan for the Greater Golden Horseshoe, 2006). These are found within the 'built-up area - conceptual' designation, basically the existing urban boundary. Surrounding this area is the 'designated Greenfield area - conceptual', an area designated by municipalities for long-term growth that has now been incorporated within the growth plan. Outside of specifying that municipalities meet certain growth targets, measured by population and employment targets, there are no targets for widespread intensification. While growth centres are useful, the most efficient form of land use that offers the positive attributes of urban areas would be a continuous urban area. In addition to this, reducing population and employment targets for municipalities outside of Toronto, but within the Greater Golden Horseshoe would help direct growth to the core.

A third policy exists to inform growth of a portion of Ontario, the Metrolinx Act. Within the Greater Toronto Area, Metrolinx is responsible for the provision of regional transit. Since transit ultimately informs the type of land use built, Metrolinx plays an essential role in the direction of growth. There is a great opportunity for Metrolinx to direct growth in the Greater Toronto Area by using part of the existing legislation. Section 20 of the Metrolinx Act (2006) states that corporation may expropriate land for the purposes of carrying out its objects. Subsection 5 (1) defines the objects of the corporation as those involved in the co- 
ordination, planning, financing, development, and implementation of a multi-modal transportation network.

Metrolinx can utilize leverage their authority to expropriate land ahead of a planned transit line and use land value capture as a mechanism to pay for the infrastructure construction while contributing to the intensification of the adjacent lands. Of course this would bring many objections from the private sector due to the omission of transparency of Metrolinx's actions, as their decisions would be in a closed-door environment; however, the benefit to the public would be outweighed by the concerns of private sector developers.

Directing growth is possible through one additional option, the Development Permit System. This tool has three main components that help build communities that are sustainable and desirable including: a policy basis within the official plan; implementing a development permit bylaw; and issuing a development permit to give planning approval (Ministry of Municipal Affairs and Housing, 2008). A streamlined planning process is one important attribute of this tool as it provides a "one-stop" planning service by replacing the regular zoning, site plan by-laws, and minor variance process into one application and approval. As a result, the process becomes more transparent, reduces risk, and is quicker through faster decisionmaking (ibid). The use of this tool must be prescribed within a Development Permit Area, set out within a municipality's official plan.

Infrastructure Ontario, a crown corporation of the Province of Ontario, is responsible for the renewal of the province's major infrastructure, including roads, water and wastewater systems. Their employment of Alternative Financing and Procurement (AFP) represents a made-in-Ontario model of project procurement that 
offers a better result for residents. Based on five principles as laid out in the Province's Building a Better Tomorrow Framework including:

- Public interest is paramount

- Value for money must be demonstrable

- Appropriate public control and ownership must be preserved

- Accountability must be maintained

- All processes must be fair, transparent and efficient.

It can be argued that if the government of Ontario is using these principles to fund key infrastructure than these principles must be applied to the scope of the project that delivers the most efficient form of land use, one that more than likely does not come from suburban sprawl.

With the amount of capital properly used among provincial agencies and corporations, the Province of Ontario is able to operate in a less risk prone " environment, allowing it to receive certain financial benefits that are not open to municipalities. Producing less risk for residents creates less risk for investors, resulting in a higher credit rating for the Province and lower interest rate costs for borrowed capital. These lower interest rates can be used as a leveraging tool against municipalities to receive cheaper capital in return for producing more efficient municipal infrastructure projects. There is merit in engaging in this strategy as the Province will become more efficient, productive, and profitable with municipalities using their resources wisely. 
Attributes, which a new development paradigm should contain, can be surmised based on the literature review after examining the Garden City model, Levittown, Reston, and Master Planned Estates. While this is not an exhaustive list of all development paradigms, the collection provides an expansive variety that has influenced suburban development throughout the $20^{\text {th }}$ century in North America. There is no qualitative and quantitative system of analysis used in the classification of positive and negative traits. The distinction between the two sides is simply based on what is typically considered good and bad from a planning perspective.

The most important attribute needed in a new development paradigm is to have social concerns inform the physical form. Physical determinism does not help aid social concerns; it only contributes to the development of other problems. Among the social concerns that need to be expressed is the necessity of building complete communities, in the context of land-use and socio'economic classes. True, complete communities require all types of land-uses and people to support these land-uses.

Once the components of a community are set, it is vital that a long-term perspective on the operation is developed. This broad perspective triggers the requirement for collective action to manage the environmental and infrastructure concerns. Collective action highlights the need for a significant government presence to work beyond a financial ideology directed by narrowly defined financial success. However, the private sector cannot be eliminated. It must play a role in the provision of services. The private sector has an inherent comparative advantage over the public sector that cannot be discounted. The organizational structure of private corporations assist greater flexibility in delivering services, ultimately delivering products and services more efficiently at lower cost. Nevertheless, it is 
important to maintain democratic control while maintaining this collective interest and individual rights.

Needs and desires of people cannot be ignored. Development must factor in different styles of development to cater to a variety of socio-economic classes. While communities must be built to accommodate all classes, they must still cater to the needs for tiered standards. Regardless of the range of quality amongst units in a development, a high-quality design must be utilized for all units to create an aesthetic appearance.

Avoiding the fallacies of other development paradigms is necessary for a new development paradigm to have an impact on changing inner-ring suburban areas. As seen from the literature, physical form often separates socioeconomic classes, contributing to an entrenchment of class and animosity. Dispersion of density further contributes to poor utilization of infrastructure as growth is often targeted at the periphery to increase the amount of integration with nature over the short term. The homogenous nature of the building typology contributes to it's institutionalization through the reassurance of the social norm. While quality design is important, the incorporation of better design features in these paradigms help to insure their survival as the design overshadows external problems. Narrow targeting of the market through monotonous design contributes to reduced opportunity for sales, which can exacerbate the economic performance of a private development.

Financing development cannot rest on uncertain sources of capital. Development must result from secure, long-term sources of funding. In circumstances where private investment is used in conjunction with governance, 
decision making must endeavour to remain with elected representatives to avoid financial motivations be the only criteria in which to judge effectiveness.

\section{One Version of the New Paradigm}

The Langstaff Gateway presents one option in which to demonstrate the opportunity to create a new community utilizing the fundamental attributes of a new development paradigm. Created in the 1920 s as a residential neighbourhood, the site experience change as industrial uses moved into the area during the 1950s. At this time, the 47 acre site is left occupied by low-density industrial and resident land uses (LDFS, 1995; LGMP, 2009; as cited in Antoine, 2011).

Now situated within the Town of Markham, this site is designed based on the principles of new urbanism (see figure 1). Four principle guide the plan including: diversity and balance; conservation and restoration; human and pedestrian scale; and connection and interdependence (p. 22, as cited in Antoine, 2011). Through the utilization of these principles, it is estimated that the entire site can accommodate a density of 1,000 residents and jobs per hectare for a total of 32,000 people and 10,000 jobs (Fleischer, 2010; LGMP, 2009; MPIR, 2006, as cited in Antoine, 2011).

Designated as an Urban Growth Centre within the Growth Plan for the Greater Golden Horseshoe, a provincially mandated growth plan, the density at which this development is proposed fits within future growth targets. Due to the isolated nature of the site from transit, there is no significant infrastructure outside of an adjacent highway to support the significant density. For this reason, the site's reliance on planned future mass-transit investments limits opportunity to grow organically without the involvement of provincial funds (for transit). 
Figure 1 - Langstaff Gateway Land Use Proposal (Ferris \& Associates, Inc, 2009)
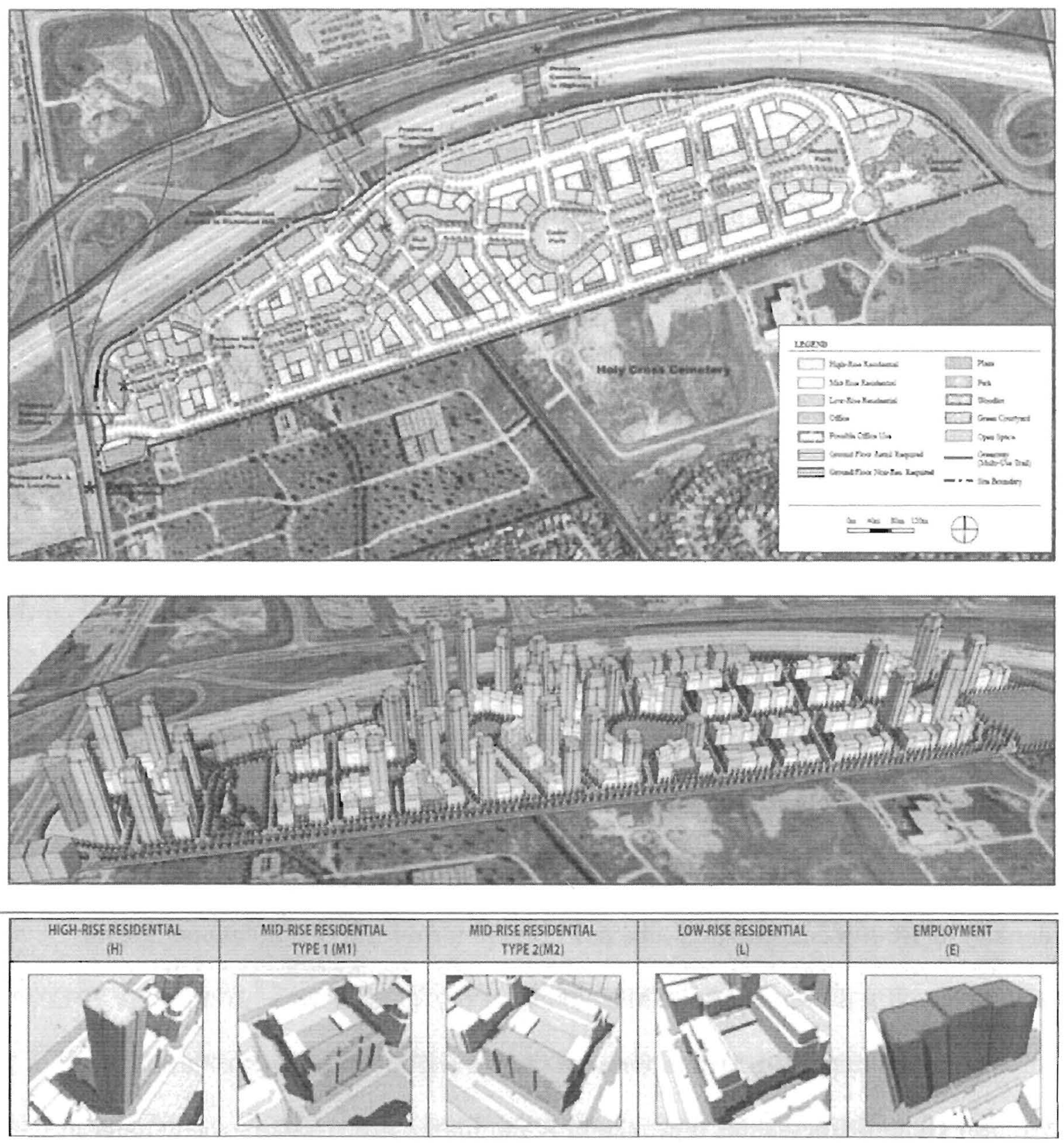
The scale of this density is quite significant and deviates greatly from the surrounding land uses. More importantly, these surrounding land uses are set back enough through the adjacent highway, cemetery and arterial road barriers. While these attributes will help the project's merits, it is an isolated site that does not fully represent the conditions found within inner-ring suburban form. More importantly, the fragmentation of property ownership within inner-ring suburban form differs greatly from the larger property parcels and reduced ownership fragmentation of the Langstaff Gateway.

Incorporated within an Urban Growth Centre, the Langstaff Gateway project will be known as a demonstration project simply based on the unique location and scale of this suburban infill development (Antoine, 2011).

\section{Using Expropriation}

Exploring the idea of expropriating inner suburban land is based on the idea that this land is not fully utilized to an optimum level. This level is undetermined, but moving towards emulating the qualities of a high-density, mixed-use environment is necessary in upgrading selected areas of cities. Privately-owned lands dominate the inner suburban area and their lack of turnover to denser land. uses is primarily the result of land-owners who desire to command significant value for their property. Price inflation is restricting developers from gaining an adequate profit in redevelopment schemes, causing them to avoid purchasing properties and consolidating them.

Providing justification for a controversial act is a necessary if anyone in government is to engage in considering the adoption of this practice. Expropriation is an established practice in Ontario. Yonge-Dundas Square is the product of an 
expropriation process conducted by the City of Toronto at the end of the $20^{\text {th }}$ Century based on a need to revitalize the existing commercial area. The municipal government expropriated a block of private commercial properties to turn the area into a public square. The Don Valley Brick Works was expropriated by the City of Toronto for conservation purposes to retain the environmental assets of the area and the heritage features.

Both cases highlight the need for government intervention to correct a market failure and lack of government regulation. In each example, a positive benefit to immediate and regional communities was found. For commercial revitalization and natural conservation to be deemed suitable reasons to expropriate public land, then the expropriation of residential land to increase quality of life and conserve land outside of the exiting urban boundary must be equally suitable reasons. Residential areas have the biggest impact on the quality of life of people compared to similar increases through commercial or conservation means. Not to say that Yonge-Dundas Square and Evergreen Brickworks are not significant enough to duplicate their success in other areas, it is that these examples are distinct to the point where their success cannot be emulated in many areas across each urban area.

Underutilized properties are found in urban and suburban areas. The potential for change is massive. The benefits outshine any found within the aforementioned examples because this proposal would create a cascading effect across the region. If expressed across North American, would drastically change our collective society, if not the direction of the world.

While expropriation is a tool used by governments as a compulsory taking with compensation of privately-owned property, it is still adopted by politicians, the 
same politicians that avoid changing land-use plans in residential areas to encourage intensification. While modifying land uses plan to encourage the market to act, the determination of residents to stay in their dwelling would likely restrict redevelopment. It is acknowledged that there are other tools that a municipality can use to encourage high-density development including: Community Improvement Plans; development charge reductions or abatements; planning policies; lower development application fees; and parkland dedication waivers.

Attempts at greater intensification have been made by the provincial government to avoid the political squabbling at the municipal level that leaves intensification stagnant. These attempts through the Provincial Policy Statement and Places to Grow Act have failed to materialize enough physical change to the built environment in the short time that they have been enacted. While endorsement of growth management at the provincial level makes it easier to engage in widespread change, the limited nature in these mandated regulations will fail to create enough change as they still endorse urban boundary expansion.

Why Expropriation

Reviewing the process of expropriation in the context of the ethical considerations is important to review the impact on the quality of life of the affected residents. Memories established in a dwelling are impossible to recreate for residents and to have government forcefully take the property with compensation could be a significant shock to their health. In light of the significant hesitation to redevelop inner suburban areas, residents must begin to wonder what they expect urban and suburban areas to resemble if the status quo continues and what implications arise from the proliferation of unsustainable development. Failure to 
intensify these areas is creating a problem of sprawl as politicians, planners, and the public see only one option to meet housing demand - horizontal expansion. So apparent is the belief that land is untouchable that politicians and planners have relegated society into believing that sprawl is the only suitable form of housing.

Pushing adoption of expropriation is based on the need to address environmental concerns about the underutilization of land and the concern about how the continuation of this land-use contradicts morality ${ }^{3}$ on regional and international scales. The needs of a few residents have to be compared against the overall benefit given to an entire region through a more efficient land use pattern. The utility of society is of greater importance than the utility of a few.

Unfortunately, the perceived impact of these residents typically outweighs the potential benefit to society based on the inability for politicians to understand the complex relationship between land use and well-being.

Our collective use of resources to sustain these single-family dwellings is significant in the context of using resources above their regenerative level. How can society morally allow an expanded use of resources to be misallocated in our contemporary generations if society is to make future generations pay for this shortsightedness?

The problem politicians, planners, and residents face right now is with admitting that this issue even exists, while not pointing the finger at ourselves and disregarding it. The majority of residents live in single-family dwellings at the same time planners are expecting people to stop this behaviour and change. Declaring that the problem even exists, in the context of morality alone, would represent such

\footnotetext{
${ }^{3}$ Morality refers to a set of personal or cultural values that inform right or wrong actions in society
} 
a political mishap that no one would dare to take it on. Realistically, the only option to facilitate such action would be to commence legal action against governments to force them to act; one issue that would present many questions. Nevertheless, this may be the only approach to correcting the problem. Climate change is an issue verified by substantial, peer-reviewed, quantitative information, yet, there is little if any legal action enforcing change to mitigate climate change. This begs the question as to how any changes to land development would arise from a legal argument against sprawl based on resource restraint and health.

Society has a misconception over the amount of space that residents need to live. The requirement of a single-family dwelling to house a growing family, let alone an elderly couple, is not essential. Societies around the world have managed to live well in multi-family dwellings for centuries. The sense of entitlement, prestige, and competition to have a house is developing a culture that cannot help but to place unattainable aspirations.

Exploring expropriation is a necessary action to correct market and political obstacles surrounding property redevelopment. Are there collective positive benefits to be accrued from removing property from an owner? Yes, significant positive externalities can be demonstrated as the result of expropriation. If planners qualify an expansion of the urban environment as a positive change, then there are many positive externalities to be found.

Entrenched beliefs of private property rights being guaranteed have left property owners with a sense of entitlement that they are the only authority in determining the direction of their property. The Crown has certain property rights derived from federal and provincial legislation that has withstood judicial challenge. Essentially, private property owners must understand that they only retain a 
temporary right to own land until such time that a government believes transfer of ownership from the private owner to the public owner is in the best interest of all. Canadians have affirmed through cultural diffusion that property rights are the same in Canada as in the United States.

The perceived set of rights that exits is a hurdle to the process and has to be examined to build up support for the process of expropriation. Often, people are outraged that the government is able to take their land and use it for some erroneous reason. Yet, governments are set up to benefit all people, in a collective manner. If land is to be expropriated, it is because a benefit is deemed to be offered. At the same time, people may believe that they may receive no money or an insignificant amount of compensation. Incorrect compensation for property is not an issue in this discussion as the value is based on market value and will eventually diminish over time as these types of property become more plentiful through the process.

Facilitating change has to be accomplished through incremental growth. Any severe shock to the market will create problem for government and individuals. It is in the best interest of society that government slowly incorporate policy changes that are stepped incrementally with full disclosure of their intent to make more information available to individuals to make informed decisions. While incremental growth is necessary, the pace of this growth is fundamental in determining the ultimate success of transforming urban and suburban regions. 
The mix between the public and private sector serves mutual interests. Planners and politicians cannot expect that either can operate in isolation. Limited interaction is currently used; the trouble is that this arrangement needs to be tweaked. Why is there any aversion to changes to the arrangement in place? Obviously these changes will present winners and losers to the status quo situation. Politicians need to understand how to make things work in the public interest. An incremental approach to planning must be undertaken. Is it better that society slowly try new things with limited amount of information? Of course, if planners are expected to gather all available information and then try to find a solution, they will end up never having enough information and take too much time to do anything.

If government is able to gain control of the key piece of the development process, then the market should be able to work on the one area that they are best at. Why is a more intimate approach to development not possible? This would solve many issues with the provision of social services, with respect to the location and scale of services. Land use planning would radically change and the use of resources, including their cost through long-term projects and economies of scale, would alter the need for market fluctuations. The best interest of the public can be served by security, the security of the future. If people are to know well in advance of the changes to their community through concrete plans to redevelop, not NIMBY("Not in my Back Yard") influenced development, then people will have greater certainty regarding their perception of space.

To say that private development would be encouraged would be an understatement. Comparing this process to the way that development takes place would result in significant changes to the cost of development. Making development 
transparent would open up the city to a RFP process, making development cheaper by having the private sector compete. Claiming this process reproduces the market mechanism is perfect as it opens up transparency to ensure that developers are not gouging consumers. While this may raise fears that trade secrets will be highlighted, public sentiment should calm those fears as people realize that everyone is expected to make a profit as well as the likelihood that developers will reduce their profit to remain in business.

City development corporations provide a venue for this process that can take over the procurement of land and allow the city to remain legally disconnected from development and direct profit. Planning must remain the sole guiding force in this process. While financial implications are noted, planning has to direct the path. Publicly-owned development corporations are currently eroding the barrier between what a municipal government did and what the private sector did. The entrenched position of both entities is evolving into one that is focused on the collective benefit of residents through the increased financial position of the municipality.

In place of the desire to benefit society through increased profit, municipalities can increase the utility of it's' residents by making development cheaper and intensifying suburban areas. The judgment of when a benefit accrues should be examined. This desire to see a benefit accrue at different stages within their existing development process creates competing interests and areas in need of discounting or favourable influence.

The process of selecting land for this process is not to be discussed in this paper. Any action to define areas of intensification will be based on sites close to existing areas on the urban fringe that are underutilized based on density. Classifying the appropriate level of density is challenging, or the density at which 
lands are considered to be underutilized, for that matter. Generally speaking, density that cannot support the maximization of higher-order transit should be removed from considerations as an adequate guide. These are important issues to resolve, nevertheless, the underlying argument that this process needs to be instituted as well as the general benefits have to be accepted.

While this paper has expressed both market and non-market solutions to facilitate inner-ring suburban redevelopment, there are many other solutions that could be highlighted for inclusion. For strategies to be included within this paper they would have to present significant opportunities to facilitate redevelopment over and above what strategies are in place at the moment. Land expropriation and prezoning, the two strategies selected in this paper, are not used on a widespread basis in Canada and offer a unique chance to try a different method of opening development opportunities.

It is assumed that any strategies largely supported by the public have already been considered, at least those that do not stir a large amount of controversy. Any policy that is new to the public will invoke feelings of NIMBYism; the key to gaining political support is to choose policies that cause the least amount of backlash. This mindset is based in a society that does not have the audacity to challenge hard issues. The distinction between hard and soft strategies is what separates strategies used here and those that are ignored. 



\section{Recommendations}

The Province of Ontario has an opportunity to increase their role beyond a facilitator of low-density municipalities. The statutory authority of the Province as the creator of municipalities is the only level of government that can facilitate the necessary level of change. A need exists to offer municipalities the ability to allow transformative change across their communities increasing densities at levels that politicians are unwilling to approve. There are existing tools that can be better utilized by municipalities and other forms of government to facilitate the intensification of inner suburban areas. Priority should be given to these tools as they will offer the easiest process to direct appropriate growth. If these tools do not work, then there are other tools that can be adopted by the Province.

To redirect growth through intensification within the inner-ring suburban areas, it is recommended that municipalities create a Development Permit System (DPS) by amending their official plan. Included within the official plan must be a delineated area where the DPS will be used; this area should contain the entire inner-ring suburban form. However, it would be more appropriate for a small area of this development type to contain a demonstration area to showcase the potential. The goals and objectives of this new paradigm must be contained within this official plan amendment to establish the vision for how the community will change. A development permit bylaw must be established as well to inform how development will take place. With this DPS in place, a municipality will be able to dictate the form, character, and density of development to ensure that the appropriate type of growth is occurring.

Further intensification can be obtained by Metrolinx utilizing the existing legislative authority to expropriate lands in carrying out the objectives of its 
mandate. It is recommended that Metrolinx engage in expropriating properties along existing transit corridors that it manages, alongside future planned corridors, in order to redevelop these lands. With these actions, Metrolinx will be able to support intensification in urban and suburban areas while subsidizing the total cost of infrastructure.

Adopting a DPS and encouraging Metrolinx to expropriate and redevelop property are two easily implemented policies that can help encourage intensification. If these are not successful, the next step is to engage in change to the Growth Plan for the Greater Golden Horseshoe and the Provincial Policy

\section{Statement.}

It is recommended that the Growth Plan include a further designation within its land use map, 'designated intensification area - conceptual', to create a zone within the core of the Greater Toronto Area that is intended to support the redevelopment of inner-ring suburban areas. This new designation would require any redevelopment be at a multi-family density that can support mass-transit. At the moment, the 'built-up area - conceptual' designation does not provide enough incentive to concentrate growth on a widespread, but concentrated basis. While the urban growth centres emphasize concentrated growth, the entire urban area would be better served if density was concentrated across an area rather than a node. It is further recommended that the intensification targets within the Growth Plan be altered to reduce the amount of growth available within outlying municipalities and shift this growth to the core. 
Within the Provincial Policy Statement, it is recommended that the Province alter the policy to specifically outline where growth should occur and at what density. While growth is directed to be within a settlement area and at an efficient density, there needs to be defined targets for this density.

It is expected that the aforementioned recommended changes to the Growth Plan and the Provincial Policy Statement will be too significant to adopt, which is why the following section is well-defined. This section is very detailed because of the need to change one particular area of the Expropriations Act to encourage easier intervention by municipalities. Among the Expropriations Act, Planning Act, and Municipal Act, municipalities have the ability to expropriate land, although, there are obstacles in acquiring land in a timely manner. If municipalities are to see real change of their inner-ring suburban areas, then expropriating land must be made more effective.

Effective change would be accomplished by giving clearer authority within the Expropriations Act (1990) to municipalities to expropriate land for the purpose of intensification. At the moment, subsection 5 (1) (a) allows the council of a municipality to expropriate lands for municipal purposes. Once notice of intention to expropriate is given, subsection 6 (2) allows a registered owner to request a hearing into the application for expropriation. However, subsection 6 (3) allows the Lieutenant Governor in Council, in special circumstances, to allow the expropriation to go forward without an inquiry procedure if he or she deems it to be necessary or expedient in the public interest. Under subsection 7 (5), an inquiry officer conducts an inquiry to determine if the expropriation of the lands of the registered owner is fair, sound and reasonably necessary in achievement of the objectives of the expropriating authority. Nevertheless, subsection 8 (1) states that the approving 
authority shall consider the report of the inquiry officer. There is no requirement that the approving authority conform to this report.

Despite the allowances of the Expropriations Act, the Municipal Act simply lays out in subsection 6 (1) the authority for municipalities to acquire land through the process of expropriation, in accordance with the Expropriations Act (1990). Other areas of the act set out instances where expropriation factor in. Subsection 6 (2) permits a municipality, with approval of the Ontario Municipal Board, to expropriate land from another municipality, local board or school board. Subsection 65 (1) states that a municipality, through building a highway past an original road allowance, will have expropriated any land that is part of that mistake and the owner is not able to bring action or try to recover the land. Subsection 65 (2) elaborates that this owner is entitled to compensation. Subsection $91(10)$ states that if a municipal public utility is built outside of a municipal road allowance, then the municipality will be deemed to have an easement on that property and the owner will be entitled to compensation.

The Planning Act (1990) references the ability for a municipality to acquire lands including: subsection 25 (1) that allows a acquisition of lands for the purpose of developing any feature of the official plan; subsection 28 (3) that allows the acquisition of lands within a Community Improvement Plan; subsection 34 (8) allows the acquisition of lands that do not conform to a zoning by-law; and subsection 42 (15) facilitating the acquisition of land for park purposes; subsection 50 (5) clause (e), where the part of a lot or block may be conveyed if the other part of the lot was acquired by expropriation; and subsection $42(10)$ for the purpose of the resolving a dispute based on not determining the value of the land between a municipality and an owner. 
With regard to the current Expropriations Act (1990), the subsection 6 (3) must be expanded to allow an approving authority to proceed with an intended expropriation without the inquiry procedure. If an approving authority is intent on expropriating a particular property, there is no subsection or clause within any of the aforementioned acts that will restrict the action. The hearing of necessity places extra burden on the municipality and the owner of land, giving the owner false hope that they can stop the action the municipality. The significant obstacle is the delay in the process. A delay only adds to the cost of the municipality as well as draw negative attention from the public. A municipality should first use section 30 to acquire property with the consent of the owner of land to reduce the amount of delay. If this process is unacceptable to the owner of land, then a municipality should revert to the revised subsection 6 (3).

To reduce the anticipated public disapproval with a prompt expropriation process and apparent unchecked power to acquire private property, subsection 6 (3) should be further elaborated to highlight the requirement that any land acquired with this section be fair, sound and reasonably necessary in achievement of the residential intensification objective set out in the Official Plan of the expropriating authority. This clause is similar to subsection 7 (5), mandating that any action to expropriate is done in a transparent manner.

With this change to the legislation, municipalities will now be authorized with one less procedural hurdle to expropriate land for the purpose of redevelopment in inner-suburban areas. This new legislated ability will help correct the market failure of private ownership of land. The changes to the legislation must coincide with changes to the municipalities' Official Plan. 
In order for municipalities to expropriate land there must be policy in place to direct growth properly. An official plan is the most appropriate municipal document to highlight its future growth. Without policy direction in place, a municipality will face pressure to use the power improperly. The public's right to understand locations of future intensification is essential and expropriation of residential properties would be one such action that must be publicized well in advance.

As the decision to expropriate is to be conducted on a qualitative and quantitative basis, a policy identifying sites based on characteristics will follow a stepped process that will identify the easiest sites to redevelop first, followed by progressively more complex ones. With this process, there is greater clarity produced to understand the direction and progress of the policy; a key consideration to encouraging the private sector to participate.

While an Official Plan currently offers information on the type of land use and built form characteristics expected in the future, the time line of such change is unknown. With the new authority offered, municipalities will have created phased redevelopment schedules to inform the course of change. Depending on the type of tenure of new development, a time line for the redevelopment should be included.

The actual action of expropriating property should be conducted through a private corporation whose sole owner is the municipality. With this arrangement, the expertise of staff will be used to guide and approve development rather than politicians. This will ensure that the most policy-based decision is made rather than one formed on political grounds. Politicians, and by extension the public, will have oversight over the operation through the process of selecting members on a board of directors. This board must incorporate and be dominated by directors from the 
private sector to bring a variety of expertise to the operation of the corporation while reducing political influence from politicians on the board.

Once property is expropriated, the private redevelopment corporation will operate on a Public-Private Partnership (P3) model whereby each development project will create a new joint company with a private corporation. Each development project will be formed through a competitive bidding process where private corporations will respond to a request for proposal (RFP). This action will ensure that the most financially suitable company will work on the project while meeting the broad sustainable goals of the municipality.

Using P3s are essential in maintaining transparency and financial accountability in the process. If expropriated land was simply open to the private sector through a competitive bidding process, then government would be doing the work of the private sector while not capturing any of the monetary benefits. Joint projects are intended to facilitate change at the lowest cost possible while delivering external benefits to the community.

Financing this process is an immense consideration, which is why it is recommended that any municipality deciding to engage in this process set up the redevelopment corporation with an initial capital reserve. This reserve will serve the need to compensate property owners for their expropriated land. When a RFP is tendered, a condition in it will state the private sector partner will have to put up suitable capital to facilitate construction and possible operation of the new residential project. The goal of this arrangement is to limit the government's liability and encourage the private sector to be more prudent with private capital, ensuring that higher quality work is delivered. 


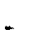




\section{Conclusion}

Anticipated improvements in health derived from the adoption of singlefamily dwellings have failed to materialize across North America due to the appearance of other unintended health concerns. This development paradigm has assisted uncontrolled economic growth, generally speaking, a positive attribute; however, unrestricted economic growth when based on resource extraction has limitations that will eventually reduce the economic viability of society. The only way to ensure society's survival is to refine our means of living, shifting away from one that consumes resources beyond the Earth's carrying capacity. At the same time, this shift will help to solve the central issue at which planning was formed as a profession. Enjoying a better quality of life, measured at the collective level, can only be found in urban environments. This ideological change must start at some point in time. Society has to re-establish its' relationship with the environment. The connection between the suburban environment in which most of North American residents live within and the natural environment that remains is often so far removed that residents have disassociated any image of what natural environment existed prior to development.

By adopting the aforementioned recommendations, development in Ontario will facilitate greater intensification in inner-suburban regions. These deviations from the status quo of development will provoke strong reaction and hesitation, especially from actors who are rewarded favourably at the expense of others. Nevertheless, our society must begin to question the path of development selected by articulating the need for a drastically different development paradigm. Without this discussion, society will inevitably use more resources to sustain our lifestyle than our planet can allow. 



\section{References}

Antoine, M. (2011). Markham's New Urbanist Paradigm: Neoliberalism, Gentrification, and Competitive Governance.

Benfante, R. (1992). Studies of Cardiovascular Disease and Cause-Specific Mortality Trends in Japanese-American Men Living in Hawaii and Risk Factor Comparisons with Other Japanese Populations in the Pacific Region: A Review. Human Biology, 64(26), 791-805.

Blais, P., \& Berridge Lewinberg Greenberg Dark Gabor Ltd. (1995). The Economics of Urban Form. Toronto: GTA Task Force.

Bloom, N. D. (2001). Suburban Alchemy: 1960s New Towns and the Transformation of the American Dream. Columbus, OH: Ohio State University Press.

Brittain, L. S. (2002). Financing Capital Expenditures. Canadian Tax Journal, $5 \propto(2)$, $552-575$.

Brown, K. W., \& Kasser, T. (2005). Are Psychological and Ecological Well-Being Compatible? The Role of Values, Mindfulness, and Lifestyle. Social Indicators Research, 74, 349-368.

Burchell, R. W., \& Mukherji, S. (2003). Conventional Development Versus Managed Growth: The Costs of Sprawl. American Journal of Public Health, 93(9), 1534. 1540.

Dewees, D. N. (2002), Pricing Municipal Services: The Economics of User Fees. Canadian Tax Journal, $50(2), 586-599$.

Duany, A., Plater-Zyberk, E., \& Speck, J. (2000). Suburban Nation: The Rise of Sprawl and the Decline of the American Dream. New York, NY: North Point Press.

Ewing, R., Schmid, T., Killingsworth, R., Zlot, A., \& Raudenbush, S. (2003). Relationship Between Urban Sprawl and Physical Activity, Obesity, and Morbidity. American Journal of Health Promotion, 18(1), 47-57.

Expropriations Act, R.S.O. 1990, c. 26.

Fan, Y., \& Song, Y. (2009). Is Sprawl Associated with a Widening Urban-Suburban Mortality Gap? Journal of Urban Health: Bulletin of the New York Academy of Medicine, $86(5), 708-728$.

Ferris \& Associates, Inc. (2009). Langstaff Land Use \& Built Form Master Plan.

Retrieved from

http://www.markham.ca/Markham/aspc/Irgfiles/langstaff_toc.pdf 
Freudenberg, N., Galea, S., \& Vlahov, D. (2005). Beyond Urban Penalty and Urban Sprawl: Back to Living Conditions as the Focus of Urban Health. Journal of Community Health, 30(1), 1-11.

Garden, F., \& Jalaludin, B. (2009). Impact of Urban Sprawl on Overweight, Obesity, and Physical Activity in Sydney, Australia. Journal of Urban Health, S6(1), 19-30.

Hardin, G. (1968). The Tragedy of the Commons. Science, 162, 1243-1248.

Harvey, D. (2008). The Right to the City. New Left Review, 53, 23-40.

Holahan, C. J. (1982). Environmental Psychology. McGraw-Hill.

Johnson, L. C. (2010). Master Planned Estates: Pariah or Panacea? Urban Policy and Research, 28(4), 375-390.

Kasser, T., \& Ryan, R. M. (1996). Further Examining the American Dream:

Differential Correlates of Intrinsic and Extrinsic Goals. Personality and Social Psychology Bulletin, 22(3), 280-287.

Kelly-Schwartz, A. C., Stockard, J., Doyle, S., \& Schlossberg, M. (2004). Is Sprawl Unhealthy?: A Multilevel Analysis of the Relationship of Metropolitan Sprawl to the Health of Individuals. Journal of Planning Education and Research, $24(2), 184-196$.

Langdon, P. (1994). A Better Place to Live. Amherst, MA: The University of Massachusetts Press.

Lee, I., Ewing, R., \& Sesso, H. (2009). The Built Environment and Physical Activity Levels: The Harvard Alumni Health Study. American Journal of Preventive Medicine, $\left.3 \lambda_{4}\right), 293 \cdot 298$.

Lewis, M. (1999). Suburban Backlash: The Battle for the World's Most Liveable City. Hawthron, VI: Bloomings Books.

March, A. (2004). Democratic Dilemmas, Planning, and Ebenezer Howard's Garden City. Planning Perspectives, 19, 409-433.

Metrolinx Act, S.O. 2006 , c. 16.

Ministry of Municipal Affairs and Housing. (2005). Provincial Policy Statement. Retrieved from http://www.mah.gov.on.ca/Asset1421.aspx

Ministry of Municipal Affairs and Housing. (2008). Development Permit System: A Handbook for Municipal Implementation. Retrieved from http://www.mah.gov.on.ca/AssetFactory.aspx?did=6131 
Ministry of Public Infrastructure Renewal. (2006). Growth Plan for the Greater Golden Horseshoe. Retrieved from https://www.placestogrow.ca/images/pdfs/FPLAN-ENG-WEB-ALL.pdf

Mirza, M. S., \& Haider, M. (2003). The State of Infrastructure in Canada: Implications for Infrastructure Planning and Policy. Montreal, PQ.

Morris, D. (1994). The Naked Ape Trilogy. London, Random House.

Morris, D. E. (2005). It's a Sprawl World After All: The Human Cost of Unplanned Growth - and Visions of a Better Future. Gabriola Island, BC: New Society Publishers,

Municipal Act, S.O. 2001, c. 25.

Places to Grow Act, S.O. 2005, c. 13.

Planning Act, R.S.0. 1990, c. 13.

Plantinga, A., \& Bernell, S. (2007). The Association Between Urban Sprawl and Obesity: Is It a Two-Way Street? Journal of Regional Science, 475), 857-879.

Princen, T. (1997). Toward a Theory of Restraint. Population and Environment, $18(3), 233-254$.

Ross, N., Crouse, D., Tremblay, S., Khan, S., Tremblay, M., \& Berthelot, J. (2007). Body Mass Index in Urban Canada: Neighborhood and Metropolitan Area Effects. American Journal of Public Health, 97(3), 500-508.

Santana, P., Santos, R., \& Nogueira, H. (2009). The link between local environment and obesity: A multilevel analysis in the Lisbon Metropolitan Area, Portugal. Social Science \& Medicine, 68(4), 601-609.

Sheldon, K. M., \& McGregor, H. A. (2000). Extrinsic Value Orientation and "The Tragedy of the Commons". Journal of Personality, $68(2), 383 \cdot 411$.

Slack, E. (2002). Municipal Finance and the Pattern of Urban Growth.

Speir, C., \& Stephenson, K. (2002). Does Sprawl Cost Us All? Isolating the Effects of Housing Patterns on Public Water and Sewer Costs. Journal of the American Planning Association, 6s(1), 56-70.

Thompson, M. (2003, November 11). Moody Blues. The Washington Times, pp. B4.

Tomalty, R., \& Skaburskis, A. (1997). Negotiating Development Charges in Ontario: Average Cost versus Marginal Cost Pricing of Services. Urban Studies, 24(12), $1987-2002$. 
Tremblay, M. S., Pérez, C. E., Ardem, C. I., Bryan, S. N., \& Katzmarzyk, P. T. (2005). Obesity, Overweight, and Ethnicity. Health Reports, 16(4), 23-34.

Von Hoffman, A. (2009). Housing and Planning: A Century of Social Reform and Local Power. Journal of the American Planning Association, 75(2), 231-244.

World Health Organization. (1948). The Constitution of the World Health Organization. Geneva, Switzerland: Author. 